\title{
Plant species diversity and assessment in Quezon Protected Landscape, Southern Luzon, Philippines
}

\author{
Gicel Christine B. Paclibar ${ }^{1, *}$ and Edwin R. Tadiosa ${ }^{2}$
}

\begin{abstract}
Quezon Protected Landscape (QPL) is a tropical rainforest situated at the southern Sierra Madre mountain range. However, it is subjected to anthropogenic pressure that poses threats to its flora and fauna. This study was conducted to describe the plant diversity, assess their ecological and conservation status, and to identify current anthropogenic threats in various vegetation types in QPL. Vegetation assessment was done using quadrat method established at different land use types wherein ninety $10 \times 10 \mathrm{~m}$ nested plots were used for trees, $5 \times 5 \mathrm{~m}$ subplots were used for herbs and shrubs, and $1 \times 1 \mathrm{~m}$ subplots were used for grasses. The study documented a total of 328 species belonging to 84 families and 208 genera with 2,737 individuals. Species diversity is high as revealed by the values obtained from species diversity (H') and species evenness ( $\mathrm{J}^{\prime}$ ) indexes. Out of 172 tree species identified, the most important species are: Parashorea malaanonan (Blanco) Merr. in the regenerating and lowland evergreen dipterocarp forest; Diospyros pyrrhocarpa Miq. in the karst forest; Leucaena leucocephala (Lam.) de Wit in the secondary forest; and Cocos nucifera $\mathrm{L}$. in the agroforest. Assessment of ecological status showed that out of 328 species, 213 (64.94\%) are native, wherein 65 (19.8\%) are endemic, and 115 $(35.06 \%)$ are introduced. Forty-five species (13.72\%) are threatened in which 25 of those are endemic in the Philippines. Overall, QPL has a wide array of plant species and threats such as the illegal extraction of natural resources, encroachment, cleanliness and presence of invasive alien species. So, it is recommended that protection and awareness campaign should be done for conservation and sustainability.
\end{abstract}

Keywords: Importance Value Index, invasive species, species diversity, threatened species, vegetation analysis

\section{Introduction}

Due to its unique topography and archipelagic nature that favor geographical isolation and endemism (Persoon \& Weerd, 2006; PTFCFI, 2015), the Philippines is home to thousands of both known and undocumented species of plants and animals (Medecilo \& Lagat, 2017). It is one of the megadiverse countries in the world and is considered as a "biodiversity superstar" (DENR-BMB, 2014). However, it is also one of the

${ }^{1}$ College of Arts and Sciences, Lyceum of the Philippines UniversityCavite, General Trias, Cavite, Philippines

${ }^{2}$ College of Science, Bulacan State University, Malolos City, Bulacan, Philippines

*Corresponding email: gicel_christine08@yahoo.com

Date Submitted: 06 July 2020

Date Accepted: 12 October 2020 global biodiversity hotspots (Keong, 2015; von Rintelen et al., 2017) because of adverse factors that threaten its biodiversity such as habitat loss and degradation, overexploitation and unsustainable use, invasive alien species (IAS), pollution, and climate change (DENR-BMB, 2014).

Several areas in the Philippines have undergone floral diversity assessment like the forest fragments in Cavite province (Causaren et al., 2017; Medecilo \& Lagat, 2017), forest cover in Busuanga, Palawan (PCI, 2006), Mt. Maculot in Batangas (Arsenio et al., 2011), Mt. Kitanglad Range Natural Park in Bukidnon (Amoroso et al., 2011), Canbantug forest in Cebu (Replan and Malaki, 2017) and other protected areas and landscapes. However, no full accounts are available of the floral diversity of Quezon Protected Landscape (QPL) yet.

Only a few studies have been conducted at QPL including plasmodial slime molds (Dagamac et al., 2014), vertebrate mega diversity and endemism (Brown et al., 2013), analysis of forest and grassland vegetation at the southwestern side of the QPL (Tadiosa et al., 2016), and the ecological niche modelling of 


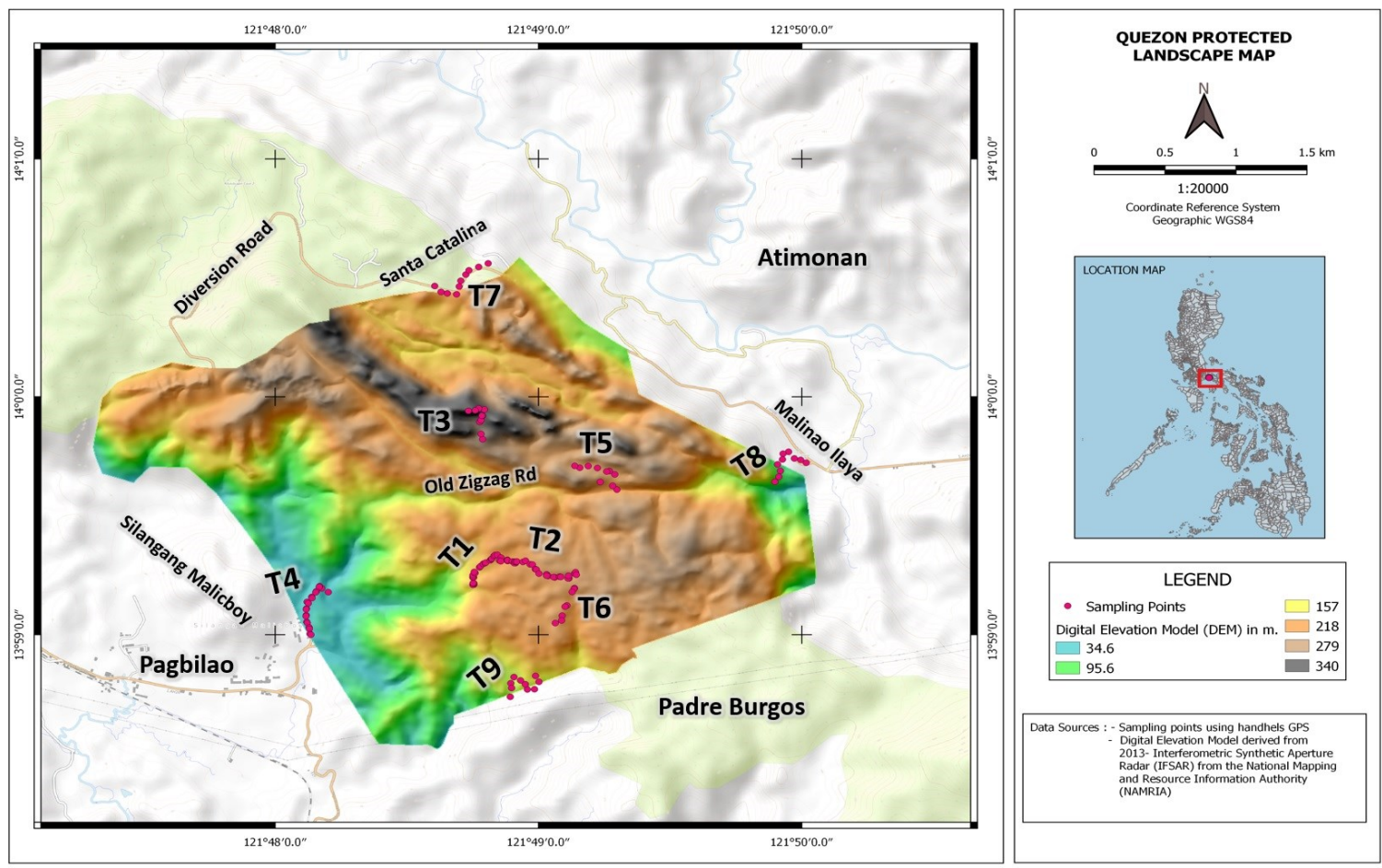

Figure 1. Geographic location of Quezon Protected Landscape showing its boundaries and 9 established transects with 90 nested plots. T1 Buenavista Spot; T2- Magnet Site; T3- Pinagbanderahan Peak; T4- Diversion Road; T5- Pinagbanderahan Foot; T6- Barangay Usli; T7- Santa Catalina; T8- Malinao Ilaya; T9- Guitong (see Table 1 for details).

invasive alien plant species (Paclibar \& Tadiosa, 2019). However, few information on the plant species present as well as species richness and ecological status are available for the QPL. It is therefore important to conduct an inventory and assessment of the flora in the said area to generate knowledge on plant diversity and status for conservation and sustainability of the remaining biodiversity. Specifically, this study aimed to evaluate plant species composition through identification and classification of different vegetation types in the QPL; determine the conservation and taxonomic status of species of plants; and identify current threats therein. The findings can be used by the DENR-Protected Area Management Board (PAMB) of the QPL in the formulation or amendment of existing policies for the protection and conservation of plant diversity especially to the threatened plant species.

\section{Materials and Methods}

\section{Prior Informed Consent (PIC)}

To comply with E.O. 247 (Bioprospecting) and R.A. 9147 (Wildlife Resources Conservation and Protection Act), the research proposal was presented to the QPL PAMB at the Community Environmental and Natural Resources Office
(CENRO) in Tayabas City, Quezon, for the approval to conduct the study and issuance of Gratuitous Permit. Permit to study was secured through PAMB Resolution 2017-04 at the DENR Regional Office in Calamba City, Laguna.

\section{Study area}

QPL is a 983.07 ha tropical rainforest (DENR Calabarzon 2013) situated between $121^{\circ} 46^{\prime} 30^{\prime \prime}$ and $121^{\circ} 50^{\prime} 00^{\prime \prime}$ East and $13^{\circ} 58^{\prime} 30^{\prime \prime}$ and $14^{\circ} 01^{\prime} 00^{\prime \prime}$ North (Proclamation No. 394) within the southern Sierra Madre mountain range (Dagamac et al., 2014). It is situated within three municipalities of Quezon province namely Atimonan, Padre Burgos and Pagbilao (Tadiosa et al., 2016). QPL is a lowland rainforest with karst landscape and several vegetation types and is considered as "very high" priority in biodiversity conservation according to the Department of Environment and Natural ResourcesProtected Areas and Wildlife Bureau (DENR-PAWB), UP Center for Integrative and Development Studies, and Conservation International-Philippines (DENR-Calabarzon, 2013). The area has two pronounced seasons (wet and dry) with $26.9^{\circ} \mathrm{C}$ average annual temperature, mean annual rainfall of $2740 \mathrm{~mm}$, and 78\% average humidity (Climate-Data.org, 2019). 
Table 1. Description of the study site.

\begin{tabular}{|c|c|c|c|c|c|}
\hline Site & Transect & Locality & Coordinates & Area & $\begin{array}{c}\text { Elevation } \\
\text { (masl) }\end{array}$ \\
\hline 1 & Buenavista Spot & $\begin{array}{l}\text { So. Amao, Malicboy, } \\
\text { Pagbilao, Quezon }\end{array}$ & $\begin{array}{l}13^{0} 59.217^{\prime} \mathrm{N} \\
121^{\circ} 48.752^{\prime} \mathrm{E}\end{array}$ & $\begin{array}{l}\text { Lowland Evergreen } \\
\text { Rainforest }\end{array}$ & 206.22 \\
\hline 2 & Magnet Site & $\begin{array}{l}\text { So. Amao, Malicboy, } \\
\text { Pagbilao, Quezon }\end{array}$ & $\begin{array}{l}13^{0} 59.307^{\prime} \mathrm{N} \\
121^{\circ} 48.910^{\prime} \mathrm{E}\end{array}$ & $\begin{array}{l}\text { Regenerating Low- } \\
\text { land Evergreen Rain- } \\
\text { forest }\end{array}$ & 241.58 \\
\hline 3 & $\begin{array}{l}\text { Pinagbanderahan } \\
\text { Peak }\end{array}$ & $\begin{array}{l}\text { Malinao Ilaya, } \\
\text { Atimonan, Quezon }\end{array}$ & $\begin{array}{l}13^{0} 59.822^{\prime} \mathrm{N} \\
121^{\circ} 48.788^{\prime} \mathrm{E}\end{array}$ & Karst Forest & 342.16 \\
\hline 4 & Diversion Road & $\begin{array}{l}\text { Malicboy, } \\
\text { Pagbilao, Quezon }\end{array}$ & $\begin{array}{l}13^{\circ} 59.179^{\prime} \mathrm{N} \\
121^{\circ} 48.202^{\prime} \mathrm{E}\end{array}$ & $\begin{array}{l}\text { Rural Residential, } \\
\text { Secondary Forest }\end{array}$ & 31.16 \\
\hline 5 & $\begin{array}{l}\text { Pinagbanderahan } \\
\text { Foot }\end{array}$ & $\begin{array}{l}\text { Malinao Ilaya, } \\
\text { Atimonan, Quezon }\end{array}$ & $\begin{array}{l}13^{\circ} 59.610^{\prime} \mathrm{N} \\
121^{\circ} 49.298^{\prime} \mathrm{E}\end{array}$ & Karst Forest & 249.5 \\
\hline 6 & Barangay Usli & $\begin{array}{l}\text { So. Usli, Sipa, } \\
\text { Padre Burgos, Quezon }\end{array}$ & $\begin{array}{l}13^{\circ} 59.252^{\prime} \mathrm{N} \\
121^{\circ} 49.144^{\prime} \mathrm{E}\end{array}$ & $\begin{array}{l}\text { Lowland Evergreen } \\
\text { Rainforest }\end{array}$ & 246.33 \\
\hline 7 & Santa Catalina & $\begin{array}{l}\text { Sta. Catalina, } \\
\text { Atimonan, Quezon }\end{array}$ & $\begin{array}{l}14^{\circ} 0.466^{\prime} \mathrm{N} \\
121^{\circ} 48.606^{\prime} \mathrm{E}\end{array}$ & Secondary Forest & 217.29 \\
\hline 8 & Malinao Ilaya & $\begin{array}{l}\text { Malinao Ilaya, } \\
\text { Atimonan, Quezon }\end{array}$ & $\begin{array}{l}13^{0} 59.723^{\prime} \mathrm{N} \\
121^{\circ} 50.017^{\prime} \mathrm{E}\end{array}$ & $\begin{array}{l}\text { Rural Residential, } \\
\text { Secondary Forest }\end{array}$ & 67.34 \\
\hline 9 & Guitong & $\begin{array}{l}\text { So. Guitong, Sipa, } \\
\text { Padre Burgos, Quezon }\end{array}$ & $\begin{array}{l}13^{\circ} 58.827^{\prime} \mathrm{N} \\
121^{\circ} 48.989^{\prime} \mathrm{E}\end{array}$ & Agroforest & 139.93 \\
\hline
\end{tabular}

\section{Transect establishment and plant enumeration}

Nine transects were established within the QPL (Fig. 1) following some of the established transects of the DENR and additional transects were established near the buffer zone (Table 1). Buenavista Spot (T1) and Barangay Usli (T6) are both lowland evergreen dipterocarp forests which have the least disturbance among all transects. Forest is still intact with a small number of introduced plants, and dipterocarps and other native woody species are abundant. Moreover, Pinagbanderahan Peak (T3) and Pinagbanderahan Foot (T5) are both karst forests. Since the QPL is open for hiking, T3 and T5 are moderately disturbed although the trail in T5 where the transect was established was already closed. In line with this, Magnet Site (T2) which is a regenerating lowland evergreen dipterocarp forest is moderately disturbed as well since the transect is along Bitukang Manok (Old Zigzag Road) which is an alternate route going to the Bicol region. Earlier tree planting efforts were evident due to a high number of mahogany trees along the Old Zigzag Road and within T5. Guitong (T9) is an agroforest since it is a coconut plantation within the vicinity of QPL. Diversion Road (T4), Santa Catalina (T7), and the Malinao Ilaya (T8) are highly disturbed secondary forests since these are located near the national road while some parts of $\mathrm{T} 4$ and $\mathrm{T} 8$ are rural residential areas.
Quadrat method using nested plots was utilized wherein each nested plot measured $10 \times 10 \mathrm{~m}$ for tree layer. Within the $10 \times 10$ plot, two sub-samplings were made: a 5 x $5 \mathrm{~m}$ subplot was laid for herbs and shrubs, and $1 \times 1 \mathrm{~m}$ for grasses (Sajise \& Cuevas, 1995). Each transect measured $500 \mathrm{~m}$ with $10 \times 10$ nested plots and an interval of $40 \mathrm{~m}$ for each plot. A total of 10 plots were laid for each $500 \mathrm{~m}$ transect. All trees with or above $10 \mathrm{~cm}$ diameter breast height $(\mathrm{DBH})$ were enumerated (Amoroso et al. 2011; Medecilo \& Lagat, 2017). Herbarium specimens and photographs of each plant species enumerated were collected and kept at the Biology laboratory at the Lyceum University of the Philippines (LPU Cavite). The identified plants were further verified at the Philippine National Herbarium (PNH) of the National Museum of Natural History in Manila. Plants were assessed and further classified using these references: De Guzman et al. (1986), Madulid (2000), Rojo (1997), Rojo (1999), Rojo and Aragones (1998), Cardenas et al. (2001), Ferreras et al. (2014) and Co's Digital Flora of the Philippines (Pelser et al., 2011).

\section{Vegetation analysis}

Transect survey and establishment of 90 sampling nested plots were carried out along the different sites within QPL (Fig. 1). Sites included were lowland evergreen dipterocarp forest (Fig. 2A), karst forest (Fig. 2B), mixed forest (Fig. 2C), agroforest (Fig. 2D), rural residential (Fig. 2E), grassland (Fig. 2F), and secondary forest (Fig. 2G). The ecological measures 


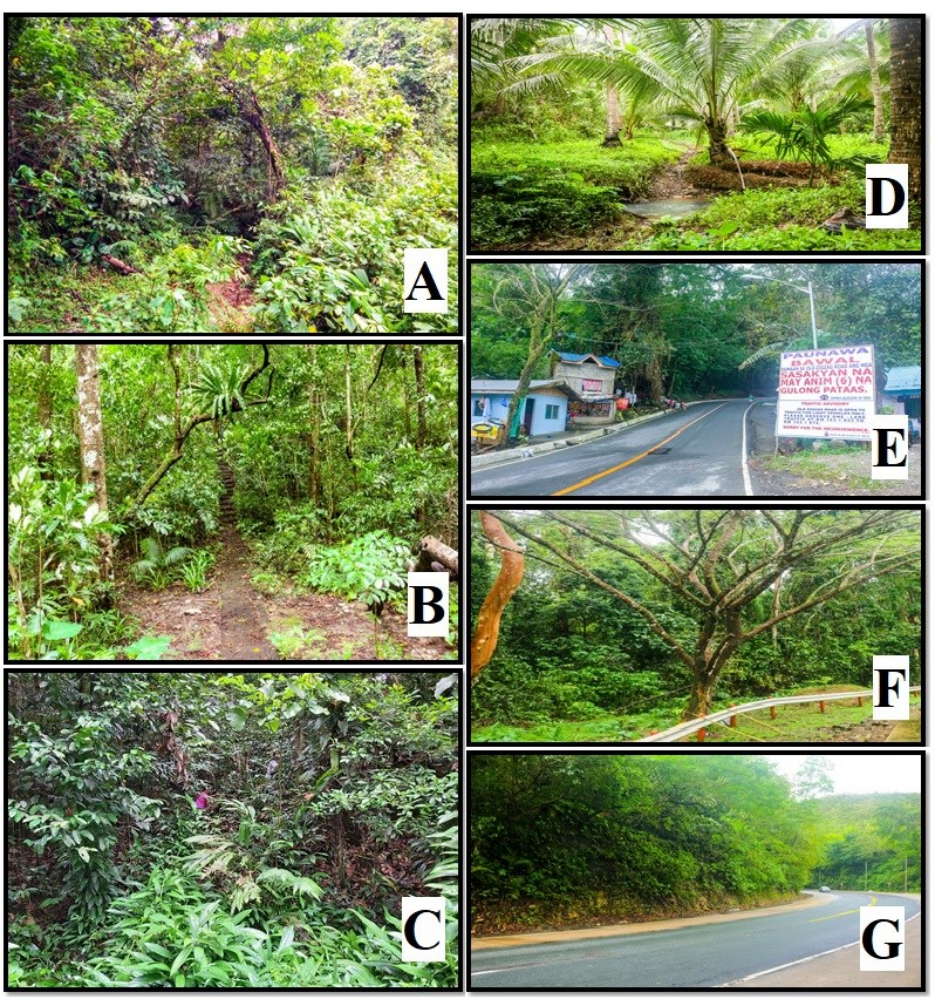

Figure 2. Area classification of the established transects. A. Lowland Evergreen Dipterocarp Forest in Pagbilao (T1) and Padre Burgos (T6); B. Karst Forest in Atimonan (T3 and T5); C. Mixed Forest in Pagbilao (T2); D. Agroforest in Padre Burgos (T9); E. Rural Residential in the Diversion Road (T4) and Malinao Ilaya (T8); F. Grassland in Pagbilao (T2); G. Secondary Forest beside the national road in Pagbilao (T4) and Atimonan (T7 and T8). See Figure 1 for the actual location.

such as species richness, species evenness, species diversity index, number of native and number of non-native plants were calculated. Species richness, number of native and non-native plants were measured through counting the species present (Borja et al., 2015). Species evenness was computed using Pielou's evenness index (Pielou, 1966) and Shannon-Wiener index was used to calculate the species diversity index (Smith and Smith, 2004). After the measurement of the DBH and its conversion to basal area, Important Value Index (IVI) was computed through the values obtained from the relative frequency, relative dominance, and relative density as prescribed by Brower and Zar (1977).

\section{Plant identification and assessment of conservation status}

The assessment of conservation status of the plants was made using references such as Fernando et al. (2008) and DENR AO No. 2017-11 with the following categories and definitions:

\section{A. Threatened Plants}

a. Critically Endangered (CR) - refers to a species, subspecies, varieties or other categories that are showing great probability of extinction in the wild in the near future.

b. Endangered (EN) - refers to a taxon which is not critically endangered but may face a very high risk of extinction in a medium-term future in the wild

c. Vulnerable (VU) - refers to a taxon which is not critically endangered nor endangered but may be endangered in the near future due to adverse factors that may threaten its population

B. Other Threatened Species (OTS) - refers to a species, subspecies, varieties, or other categories (taxon) that is not critically endangered, endangered, nor vulnerable but may fall in the vulnerable category in the future due to the adverse factors that may threaten its population.

C. Other Wildlife Species (OWS) - refers to a taxon which is comprised of non-threatened species but have the tendency to become threatened in the near future and be listed in the threatened category upon the recommendation of the National Wildlife Management Committee.

\section{Results and Discussion}

\section{Plant species diversity}

A total of 2,737 plant individuals belonging to 84 families, 208 genera and 328 plant species were identified in the established transects at QPL wherein 213 were native and 115 were non-native (Table 2). Among these native plants, 148 were not endemic and 65 were endemic. The list of individuals together with their respective family, ecological status, and conservation status are presented in Table 4. Among the 84 families, the Fabaceae had the greatest number of genera and number of species with a total of 18 and 21, respectively. Among the transects established, Transect 6 (Barangay Usli) had the most number of species and species diversity was high as shown by the obtained $H^{\prime}$ index, which fell within the substantial range from 1.5 to 3.5 (Magurran, 1988), and J' index wherein the index value (observed distribution) ranged from 0.79 to 0.95 which is close to the maximum value of 1 (expected distribution) (Camargo, 1995). The most diverse among transects was Barangay Usli (T6) having the highest $\mathrm{H}^{\prime}$ index and J' index of 3.04 and 0.95 , respectively. The result could be attributed to its area classification in which high species diversity occurred with least level of disturbance (Petraitis et al., 1989). On the other hand, the least diverse among transects were Santa Catalina (T7) and diversion road (T4) having the lowest H' index (2.12) and J' index (0.81), respectively. The results 
Table 2. Assessment of plant species composition, ecological structure and status. Sp. - Species; Ind. - Individual; H'-Shannon's Diversity Index; SE- Species Evenness; NE - Non-endemic; E - Endemic.

\begin{tabular}{|c|l|l|l|l|l|l|l|l|l|l|}
\hline Site & Family & Genus & Sp. & Ind. & H' & SE & $\begin{array}{c}\text { Native } \\
\text { NE }\end{array}$ & \multicolumn{1}{|c|}{ E } & \multicolumn{1}{|c|}{ Total Native } & Non-native \\
\hline 1 & 49 & 85 & 112 & 339 & 2.57 & 0.85 & 58 & 31 & $89(79.46 \%)$ & $23(20.54 \%)$ \\
\hline 2 & 40 & 68 & 83 & 295 & 2.18 & 0.79 & 44 & 16 & $60(72.29 \%)$ & $23(27.71 \%)$ \\
\hline 3 & 51 & 73 & 85 & 278 & 2.2 & 0.83 & 40 & 14 & $54(63.53 \%)$ & $31(36.47 \%)$ \\
\hline 4 & 37 & 65 & 79 & 276 & 2.13 & 0.81 & 33 & 8 & $41(51.9 \%)$ & $38(48.1 \%)$ \\
\hline 5 & 44 & 76 & 101 & 348 & 2.87 & 0.93 & 59 & 22 & $81(80.2 \%)$ & $20(19.8 \%)$ \\
\hline 6 & 50 & 86 & 117 & 376 & 3.04 & 0.95 & 58 & 30 & $88(75.21 \%)$ & $29(24.79 \%)$ \\
\hline 7 & 33 & 46 & 57 & 251 & 2.12 & 0.87 & 23 & 9 & $32(56.14 \%)$ & $25(43.86 \%)$ \\
\hline 8 & 42 & 66 & 78 & 257 & 2.28 & 0.89 & 38 & 9 & $47(60.26 \%)$ & $31(39.74 \%)$ \\
\hline 9 & 41 & 68 & 74 & 317 & 2.58 & 0.88 & 36 & 16 & $52(70.27 \%)$ & $22(29.73 \%)$ \\
\hline Total & 84 & 208 & 328 & 2737 & & & 148 & 65 & $213(64.94 \%)$ & $115(35.06 \%)$ \\
\hline
\end{tabular}

obtained were in line with the study of Nijs et al. (2012) that found species richness was lower in highly disturbed areas compared to undisturbed areas or areas with low disturbance. Species accumulation curve (Fig. 3) showed the increase of species per plot in each sampling site. Furthermore, as the size of the sampling site increased, the number of species also increased but the occurrence of new species decreased. In accordance with Magurran (1988), the representative sampling area is reached if the increase of number of species per unit area is below $10 \%$ with an additional $10 \%$ expansion of the sampling area. As shown in the figure, the number of species started to decline when the sampling point reached $600 \mathrm{~m}^{2}$ area. The results coincided with those of Polinar and Muuss (2010) wherein the minimum required study area was $<10,000 \mathrm{~m}^{2}$. The results suggested that the sampling points can satisfy the assessment of the diversity based on the trend shown in the graph, but additional sampling points can be added to achieve maximum decline in the addition of new species.

\section{Vegetation types in QPL}

A total of 172 tree species were recorded among the 328 plant species in the established transects. The important tree species per site and vegetation site are listed in Table 3. In the lowland evergreen rainforest, Parashorea malaanonan (Blanco) Merr. (Dipterocarpaceae) had the highest IVI followed by other native species such as Diospyros pyrrhocarpa Miq. (Ebenaceae), Macaranga tanarius (L.) Müll. Arg. in DC. (Euphorbiaceae), Ficus nota (Blanco) Merr. (Moraceae), and Hopea malibato Foxw. (Dipterocarpaceae). In the study of Borja et al. (2015), it was mentioned that P. malaanonan was the most abundant among dipterocarp species in their study site at Mount Makiling Forest Reserve (MMFR). Moreover, $P$. malaanonan could be found at areas where native species are abundant, and it is negatively associated with exotic coffee species. In line with this, Dipterocarpaceae species are typically known as climax species wherein they normally thrive and success rates are higher in low disturbance level (Brearly et al., 2017) so one can infer from the result that the lowland evergreen rainforest in QPL has low disturbance level as exemplified by tree species that mostly belong to the Dipterocarpaceae and Ebenaceae. It is worth noting that M. tanarius was also one of the important tree species in the area suggesting that the lowland evergreen rainforest had disturbed parts since $M$. tanarius is usually found in areas with disturbance and can colonize gaps even in an intact forest (CABI, 2020). To add, M. tanarius is a highly invasive alien species in other countries (CABI, 2020). In the mixed forest or regenerating lowland evergreen rainforest, $P$. malaanonan, M. tanarius, and Ficus variegata Blume are the notable most important species. The result in the mixed forest was expected since parts of the forests were disturbed because it is near the road. In the karst forest, the most notable important tree species were D. pyrrhocarpa (Ebenaceae), Pouteria macrantha (Merr.) Baehni (Sapotaceae), Strombosia philippinensis (Baill.) Rolfe (Olacaceae), Syzygium nitidum Benth. (Myrtaceae), and Pisonia umbellifera (J.R. Forst. \& G. Forst.) Seem. (Nyctaginaceae). Karst forest is dominated by native species that are mostly found in low disturbance area. Also, only one invasive alien species was present in the karst forest, Triplaris cumingiana Fisch. \& Mey, suggesting that the forest was still intact since invasive alien species highly penetrated forest gaps and were favored by disturbance (Paclibar \& Tadiosa, 2019). In the secondary forest, M. tanarius, Swietenia macrophylla King (Meliaceae), Ficus ampelas Burm.f. (Moraceae), Leucaena leucocephala (Lam.) de Wit (Fabaceae), Acalypha indica L. (Euphorbiaceae), and Ficus septica Burm.f (Moraceae) may be found. Secondary forests in 
Paclibar \& Tadiosa: Plant species diversity and assessment in Quezon Protected Landscape, Philippines

Table 3. Important plant species with highest Importance Value Indices (IVI) per established transect and per vegetation type.

\begin{tabular}{|c|c|c|c|}
\hline Site & Vegetation Type & Most Important Species & IVI \\
\hline \multirow{3}{*}{1} & \multirow{3}{*}{ Lowland Evergreen Rainforest } & Parashorea malaanonan (Blanco) Merr. & 9.26 \\
\hline & & Diospyros pyrrhocarpa Miq. & 8.5 \\
\hline & & Macaranga tanarius (L.) Müll.Arg. & 8.32 \\
\hline \multirow{3}{*}{2} & \multirow{3}{*}{$\begin{array}{l}\text { Regenerating Lowland Evergreen } \\
\text { Dipterocarp Forest }\end{array}$} & Parashorea malaanonan (Blanco) Merr. & 14.2 \\
\hline & & Macaranga tanarius (L.) Müll.Arg. & 8.38 \\
\hline & & Ficus variegata Blume & 8.34 \\
\hline \multirow{3}{*}{3} & \multirow{3}{*}{ Karst Forest } & Diospyros pyrrhocarpa Miq. & 9.99 \\
\hline & & Pouteria macrantha (Merr.) Baehni & 9.7 \\
\hline & & Syzygium nitidum Benth. & 9.21 \\
\hline \multirow{3}{*}{4} & \multirow{3}{*}{ Rural Residential, Secondary Forest } & Macaranga tanarius (L.) Müll.Arg. & 14.34 \\
\hline & & Swietenia macrophylla King & 14.18 \\
\hline & & Ficus ampelas Burm.f. & 10.77 \\
\hline \multirow{3}{*}{5} & \multirow{3}{*}{ Karst Forest } & Strombosia philippinensis (Baill.) Rolfe & 9.09 \\
\hline & & Pouteria macrantha (Merr.) Baehni & 8.55 \\
\hline & & Pisonia umbellifera (J.R.Forst. \& G.Forst.) Seem. & 8.31 \\
\hline \multirow{3}{*}{6} & \multirow{3}{*}{ Lowland Evergreen Rainforest } & Parashorea malaanonan (Blanco) Merr. & 10.82 \\
\hline & & Ficus nota (Blanco) Merr. & 7.42 \\
\hline & & Hopea malibato Foxw. & 7.4 \\
\hline \multirow{3}{*}{7} & \multirow{3}{*}{ Secondary Forest } & Leucaena leucocephala (Lam.) de Wit & 18.48 \\
\hline & & Acalypha indica $\mathrm{L}$. & 15.55 \\
\hline & & Macaranga tanarius (L.) Müll.Arg. & 11.1 \\
\hline \multirow{3}{*}{8} & \multirow{3}{*}{ Rural Residential, Secondary Forest } & Swietenia macrophylla King & 12.5 \\
\hline & & Ficus septica Burm.f. & 10.19 \\
\hline & & Macaranga tanarius (L.) Müll.Arg. & 9.48 \\
\hline \multirow{3}{*}{9} & \multirow{3}{*}{ Agroforest } & Cocos nucifera L. & 12.3 \\
\hline & & Alstonia macrophylla Wall. ex G.Don & 9.86 \\
\hline & & Macaranga tanarius (L.) Müll.Arg. & 9.32 \\
\hline
\end{tabular}

QPL were highly disturbed areas mostly found along the road and near the boundary and buffer zone wherein rural residences were present. Species of the Euphorbiaceae often play a major role as dominant species especially in disturbed and severely grazed mountain parts (Pahlevani \& Akhani, 2011) as demonstrated by $M$. tanarius and $A$. indica as among the most important species. M. tanarius, S. macrophylla, and $L$. leucocephala are all invasive alien species (Witt, 2017; Paclibar \& Tadiosa, 2019) and these plants dominated the secondary forest signifying a threat to the native and endemic flora in QPL. Lastly, agroforest was comprised of Cocos nucifera L. (Arecaceae), Alstonia macrophylla Wall. ex G. Don (Apocynaceae), and M. tanarius. The result from the agroforest was also expected since it is a coconut plantation. All in all, $M$. tanarius had high IVI in all the vegetation types except in karst forest suggesting that the vegetation types in QPL were experiencing low to high disturbance level which may negatively affect the diversity of the plant species if no intervention will take place.

\section{Assessment of conservation status}

The assessment of ecological status showed that out of 328 plant species recorded, 213 (64.94\%) are native, of which $65(19.82 \%)$ of the total of plants documented are endemic, and $115(35.06 \%)$ are introduced/nonnative species. Endemicity within the established transects in QPL ranged from $10 \%$ to $27 \%$. A total of $20 \%$ for all the transects in QPL was acquired which was quite low compared to the substantial range of 45$60 \%$ plant endemism in the Philippines such as the results of Mittermeier et al. (1999). The percentage of native species ranged from $40-58 \%$ while the introduced/nonnative species ranged from $20-48 \%$ with a total of $45 \%$ and $35 \%$, respectively.

The conservation assessment of various plant species was carried out to establish the basis for monitoring, protection, and conservation of plants at QPL. Out of the 328 plant species identified, 45 (13.72\%) were listed as threatened (Table 3). Out 


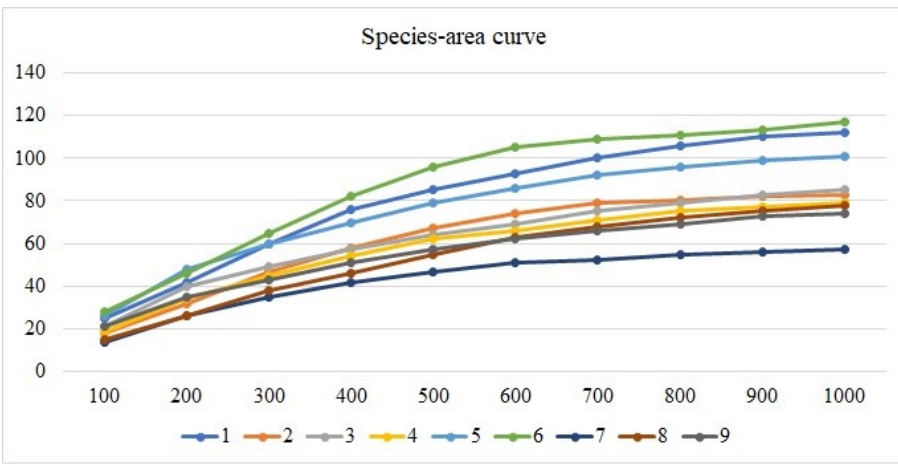

Figure 3. Species-area curve of the established transects. x-axissquare meters; y-axis - number of species; numbers correspond to various numbered sites.

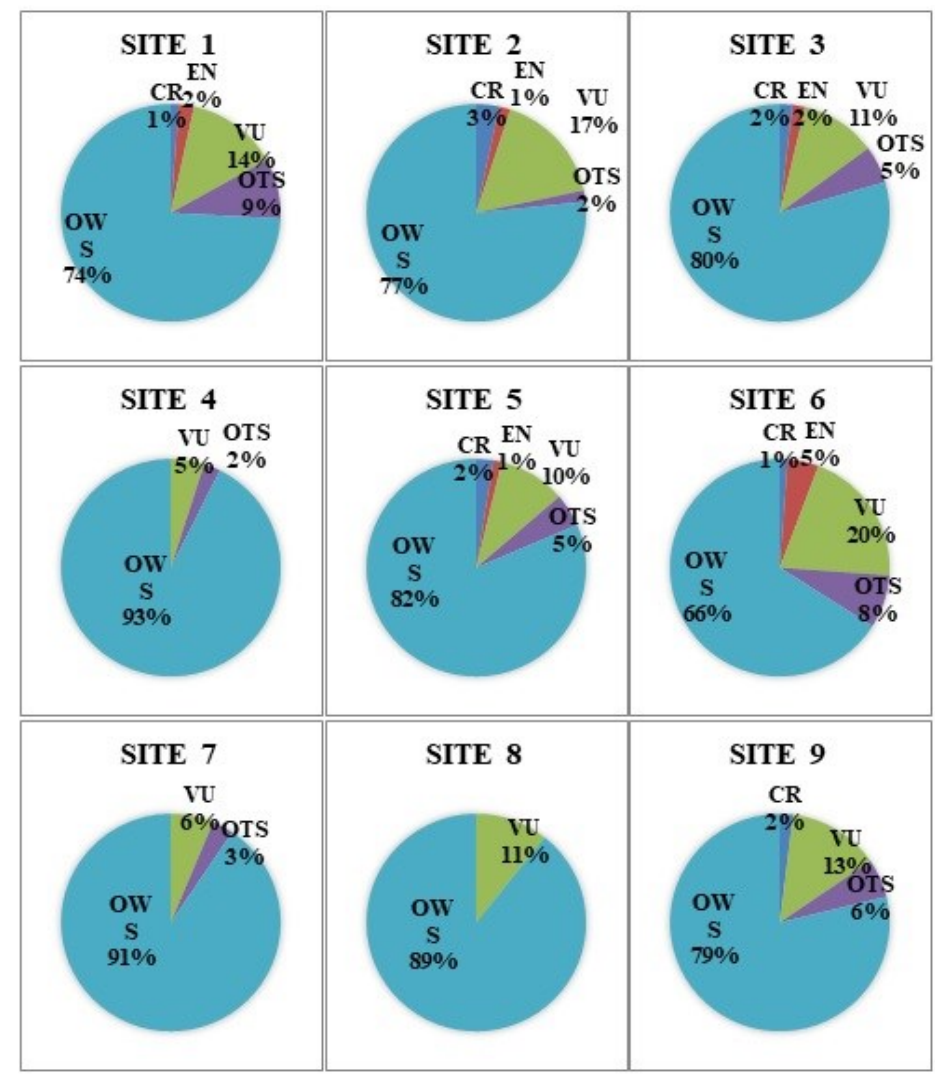

Figure 4. Assessment of conservation status of native plant species in the established transects. CR- Critically Endangered; EN- Endangered; VU- Vulnerable; OTS- Other Threatened Species; OWS- Other Wildlife Species; \%- Percentage; * List based on DENR A.O. No. 2017 -11 List of Threatened Philippine Plants and their Categories. (See Table 4 for assessment per species and their respective categories).

of all the threatened species, 12 were other threatened species (OTS), 25 were vulnerable (VU), 4 were endangered (EN), and 4 were critically endangered (CR) (Table 4). The four critically endangered plant species are Hopea malibato Foxw. (Dipterocarpaceae), Shorea astylosa Foxw. (Dipterocarpaceae),
Diospyros ferrea Kosterm. (Ebenaceae), and D. poncei Merr. (Ebenaceae). The Dipterocarpaceae had the highest number of threatened species among the families identified. This is in agreement with the study of Fernando et al. (2008) who stated that Dipterocarpaceae is one of the main families that account for majority in the list of threatened plant species in the Philippines. Since dipterocarps are the most important timber producing trees in the Philippines, it is prone to overexploitation and illegal logging leading to deforestation (Rojo, 2000). Out of 65 identified endemic species, 3 were critically endangered, 2 endangered, 13 vulnerable, and 7 were other threatened species. S. astylosa is a critically endangered endemic species that was identified in an agroforest where moderate disturbance was observed. Most of the threatened species were found at the lowland evergreen forest which also hosted the greatest number of endemic species. Moreover, highly disturbed areas have threatened species as well, so protection and conservation efforts should be done to limit the site's disturbance caused by anthropogenic activities.

\section{Threats to $Q P L$}

Some threats that were identified in this study included illegal collection of natural resources, encroachment, cleanliness, and invasive alien species. The sale of seedlings of different trees was noticed near the entrance of the Old Zigzag Road wherein most of these were mahogany (Fig. 5A). There were earlier records showing people collecting the land snail "bayuko" (Ryssota ovum Valenciennes) or edible snails, but no new reports of collection are known (Fig. 5C). Also, encroachment was observed near the QPL boundary and buffer zone consisting of tenured and non-tenured residents (Fig. 5D). Human population could be a contributing factor for the higher number of non-native plants compared to native plants (Spear et al., 2013) which may result in low species diversity if the human settlement within the area will not be prevented. Water tapping or illegal extraction of water (Fig. 5A) for car washing business and domestic consumption at the New Diversion Road was observed (Fig. 5E). The wastewater from the car wash directly flowed to the QPL without any proper wastewater system which contributed to cleanliness problem in the area. Moreover, many travellers were littering along the road. The management was religiously maintaining the cleanliness of the QPL through their clean up drive. QPL has several roads like the New Diversion Road and the Bitukang Manok which both serve as main routes going to the Bicol region (Fig. 5B). Lembrechts et al. (2016) found that mountain roads facilitate the range dynamics of most of the non-native species in having higher ranges in elevation and broader amplitudes in roadsides. Invasive alien plant species that were present in QPL are 
Table 4. Taxonomic listing of plants arranged alphabetically by family. ES - Ecological Status (N/E- Native/ Endemic; I- Nonnative or Introduced); CS- Conservation Status (CR- Critically Endangered; EN- Endangered; VU- Vulnerable; OTS- Other Threatened Species; OWSOther Wildlife Species) based on DENR AO. No. 2017-11 List of Threatened Philippine Plant and their Categories.

\begin{tabular}{|c|c|c|c|}
\hline Family & Scientific Name & ES & CS \\
\hline Amaranthaceae & Amaranthus spinosus L. & I & \\
\hline Anacardiaceae & Buchanania arborescens (Blume) Blume & $\mathrm{N}$ & OWS \\
\hline Anacardiaceae & Dracontomelon edule (Blanco) Skeels & $\mathrm{N}$ & OWS \\
\hline Anacardiaceae & Koordersiodendron pinnatum (Blanco) Merr. & $\mathrm{N}$ & OTS \\
\hline Anacardiaceae & Mangifera altissima Blanco & $\mathrm{N}$ & $\mathrm{VU}$ \\
\hline Anacardiaceae & Mangifera indica $\mathrm{L}$. & I & \\
\hline Anacardiaceae & Semecarpus cuneiformis Blanco & $\mathrm{N}$ & OWS \\
\hline Anacardiaceae & Semecarpus longifolius Blume & $\mathrm{N}$ & OWS \\
\hline Anacardiaceae & Semecarpus sp. & $\mathrm{N}$ & OWS \\
\hline Annonaceae & Annona muricata $\mathrm{L}$. & I & \\
\hline Annonaceae & Cananga odorata (Lam.) Hook.f. \& Thomson & $\mathrm{N}$ & OWS \\
\hline Annonaceae & Goniothalamus elmeri Merr. & $\mathrm{N} / \mathrm{E}$ & OWS \\
\hline Annonaceae & Mitrephora lanotan (Blanco) Merr. & $\mathrm{N} / \mathrm{E}$ & OTS \\
\hline Annonaceae & Uvaria rufa (Dunal) Blume & I & \\
\hline Apiaceae & Centella asiatica (L.) Urban & I & \\
\hline Apocynaceae & Alstonia macrophylla Wall. ex G.Don & $\mathrm{N}$ & OWS \\
\hline Apocynaceae & Alstonia scholaris (L.) R.Br. & $\mathrm{N} / \mathrm{E}$ & OWS \\
\hline Apocynaceae & Tabernaemontana pandacaqui Poir. & $\mathrm{N}$ & OWS \\
\hline Apocynaceae & Urceola laevigata (Juss.) D.J.Middleton \& Livsh & $\mathrm{N}$ & OWS \\
\hline Apocynaceae & Voacanga globosa (Blanco) Merr. & $\mathrm{N} / \mathrm{E}$ & OWS \\
\hline Araceae & Alocasia heterophylla (C.Presl) Merr. & $\mathrm{N} / \mathrm{E}$ & OWS \\
\hline Araceae & Alocasia macrorrhizos L. & $\mathrm{N}$ & OWS \\
\hline Araceae & Alocasia sp. & I & \\
\hline Araceae & Amorphophallus campanulatus Blume ex Decne. & I & \\
\hline Araceae & Caladium sp. & $\mathrm{N}$ & OWS \\
\hline Araceae & Colocasia esculenta (L.) Schott in Schott \& Endl. & $\mathrm{N}$ & OWS \\
\hline Araceae & Epipremnum pinnatum (L.) Engl. & $\mathrm{N}$ & OWS \\
\hline Araceae & Homalomena philippinensis Engl. ex Engl. \& K.Krause & $\mathrm{N} / \mathrm{E}$ & OWS \\
\hline Araceae & Schismatoglottis calyptrata (Roxb.) Zoll. \& Moritzi & I & \\
\hline Araceae & Xanthosoma sagittifolium (L.) Schott & I & \\
\hline Araliaceae & Polyscias nodosa (Blume) Seem. & $\mathrm{N} / \mathrm{E}$ & OWS \\
\hline Arecaceae & Areca catechu $\mathrm{L}$. & $\mathrm{N} / \mathrm{E}$ & OWS \\
\hline Arecaceae & Arenga pinnata (Wurmb.) Merr. & $\mathrm{N}$ & OWS \\
\hline Arecaceae & Calamus merrillii Becc. & $\mathrm{N} / \mathrm{E}$ & OTS \\
\hline Arecaceae & Calamus mindorensis Becc. & $\mathrm{N} / \mathrm{E}$ & OWS \\
\hline Arecaceae & Calamus ornatus Blume & $\mathrm{N}$ & OTS \\
\hline Arecaceae & Calamus ramulosus Becc. & $\mathrm{N}$ & OWS \\
\hline Arecaceae & Calamus sp. & $\mathrm{N}$ & OWS \\
\hline
\end{tabular}


Cont'd Table 4. Taxonomic listing of plants arranged alphabetically by family.

\begin{tabular}{|c|c|c|c|}
\hline Family & Scientific Name & ES & CS \\
\hline Arecaceae & Calamus sp. & $\mathrm{N}$ & OWS \\
\hline Arecaceae & Calamus curanii (Becc.) W.J.Baker & $\mathrm{N} / \mathrm{E}$ & VU \\
\hline Arecaceae & Calamus sp. & $\mathrm{N}$ & OWS \\
\hline Arecaceae & Caryota cumingii Lodd. ex C.Mart. & $\mathrm{N} / \mathrm{E}$ & OWS \\
\hline Arecaceae & Caryota rumphiana Mart. & $\mathrm{N} / \mathrm{E}$ & OWS \\
\hline Arecaceae & Caryota sp. & $\mathrm{N}$ & OWS \\
\hline Arecaceae & Cocos nucifera $\mathrm{L}$. & I & \\
\hline Arecaceae & Daemonorops mollis (Blanco) Merr. & $\mathrm{N} / \mathrm{E}$ & OTS \\
\hline Arecaceae & Livistona rotundifolia (Lam.) Mart. & $\mathrm{N}$ & OTS \\
\hline Arecaceae & Oncosperma tigillarium (Jack) Ridl. & $\mathrm{N}$ & VU \\
\hline Asparagaceae & Sanseviera trifasciata Prain & I & \\
\hline Aspleniaceae & Asplenium macrophyllum Sw. & $\mathrm{N}$ & OWS \\
\hline Aspleniaceae & Asplenium nidus L. & $\mathrm{N}$ & OWS \\
\hline Aspleniaceae & Asplenium sp. & $\mathrm{N}$ & OWS \\
\hline Asteraceae & Chromolaena odorata (L.) R.M.King \& H.Rob. & I & \\
\hline Asteraceae & Ageratum conyzoides L. & I & \\
\hline Asteraceae & Blumea balsamifera (L.) DC. & I & \\
\hline Asteraceae & Elephantopus tomentosus L. & I & \\
\hline Asteraceae & Mikania cordata (Burm.f.) B.L.Rob. & I & \\
\hline Asteraceae & Vernonia arborea Welw. ex O.Hoffm. & I & \\
\hline Asteraceae & Vernonia vidalii Merr. & $\mathrm{N}$ & OWS \\
\hline Athyriaceae & Diplazium esculentum (Retz.) Sw. & I & \\
\hline Begoniaceae & Begonia copelandii Merr. & $\mathrm{N} / \mathrm{E}$ & OWS \\
\hline Bignoniaceae & Dolichandrone spathacea (L.f.) K.Schum. & I & \\
\hline Bignoniaceae & Radermachera pinnata (Blanco) Seem. & $\mathrm{N}$ & OWS \\
\hline Burseraceae & Canarium asperum Benth. & $\mathrm{N} / \mathrm{E}$ & OWS \\
\hline Burseraceae & Canarium hirsutum Willd. & $\mathrm{N}$ & OWS \\
\hline Burseraceae & Canarium ovatum Engl. & $\mathrm{N} / \mathrm{E}$ & OTS \\
\hline Burseraceae & Canarium sp. & $\mathrm{N}$ & OWS \\
\hline Calophyllaceae & Calophyllum blancoi Planch. \& Triana & $\mathrm{N} / \mathrm{E}$ & OWS \\
\hline Calophyllaceae & Calophyllum inophyllum L. & $\mathrm{N}$ & OWS \\
\hline Cannabaceae & Celtis luzonica Warb. & $\mathrm{N} / \mathrm{E}$ & OWS \\
\hline Cannabaceae & Celtis sp. & $\mathrm{N}$ & OWS \\
\hline Capparaceae & Cleome spinosa Jacq. & I & \\
\hline Cardiopteridaceae & Gonocaryum calleryana Baill. & I & \\
\hline Caricaceae & Carica papaya L. & I & \\
\hline Casuarinaceae & Gymnostoma rumphianum (Jungh. ex de Vriese) L.A.S. Johnson & $\mathrm{N}$ & OWS \\
\hline Casuarinaceae & Gymnostoma sp. & I & \\
\hline Casuarinaceae & Gymnostoma sumatranum (Jungh. ex de Vriese) L.A.S. Johnson & I & \\
\hline Combretaceae & Terminalia citrina (Gaertn.) Roxb. ex Flem & $\mathrm{N}$ & OWS \\
\hline
\end{tabular}


Cont'd Table 4. Taxonomic listing of plants arranged alphabetically by family.

\begin{tabular}{|c|c|c|c|}
\hline Family & Scientific Name & ES & CS \\
\hline Combretaceae & Terminalia foetidissima Griff. & $\mathrm{N}$ & OWS \\
\hline Combretaceae & Terminalia microcarpa Decne. & $\mathrm{N}$ & OWS \\
\hline Commelinaceae & Commelina benghalensis $\mathrm{L}$. & I & \\
\hline Commelinaceae & Zebrina pendula Schnizl. & $\mathrm{I}$ & \\
\hline Convolvulaceae & Ipomoea batatas (L.) Poir & I & \\
\hline Cornaceae & Alangium javanicum (Blume) Wangerin in Engl. \& Prantl. & I & \\
\hline Cucurbitaceae & Gynostemma pentaphyllum (Thunb.) Makino & I & \\
\hline Cucurbitaceae & Melothria pendula L. & I & \\
\hline Cucurbitaceae & Trichosanthes bracteata (Lam.) Voigt & I & \\
\hline Cyatheaceae & Cyathea contaminans (Wall. ex Hook.) Copel. & $\mathrm{N}$ & OWS \\
\hline Cyperaceae & Cyperus kyllingia Endl. & I & \\
\hline Cyperaceae & Fimbristylis globulosa (Retz.) Kunth & I & \\
\hline Cyperaceae & Scleria scrobiculata Nees \& Meyen & I & \\
\hline Dilleniaceae & Dillenia luzonensis (S.Vidal) Merr. & $\mathrm{N} / \mathrm{E}$ & VU \\
\hline Dilleniaceae & Dillenia philippinensis Rolfe & $\mathrm{N} / \mathrm{E}$ & OWS \\
\hline Dilleniaceae & Tetracera scandens (L.) Merr. & $\mathrm{N}$ & OWS \\
\hline Dilleniaceae & Tetracera sp. & $\mathrm{N}$ & OWS \\
\hline Dipterocarpaceae & Anisoptera thurifera (Blanco) Blume & $\mathrm{N}$ & OWS \\
\hline Dipterocarpaceae & Dipterocarpus grandiflorus (Blanco) Blanco & $\mathrm{N}$ & VU \\
\hline Dipterocarpaceae & Dipterocarpus hasseltii Blume & $\mathrm{N}$ & VU \\
\hline Dipterocarpaceae & Dipterocarpus kerrii King & $\mathrm{N}$ & OWS \\
\hline Dipterocarpaceae & Hopea acuminata Merr. & $\mathrm{N} / \mathrm{E}$ & EN \\
\hline Dipterocarpaceae & Hopea malibato Foxw. & $\mathrm{N} / \mathrm{E}$ & $\mathrm{CR}$ \\
\hline Dipterocarpaceae & Parashorea malaanonan (Blanco) Merr. & $\mathrm{N}$ & OWS \\
\hline Dipterocarpaceae & Shorea astylosa Foxw. & $\mathrm{N} / \mathrm{E}$ & $\mathrm{CR}$ \\
\hline Dipterocarpaceae & Shorea contorta S.Vidal & $\mathrm{N} / \mathrm{E}$ & VU \\
\hline Dipterocarpaceae & Shorea falciferoides Foxw. & $\mathrm{N} / \mathrm{E}$ & VU \\
\hline Dipterocarpaceae & Shorea guiso (Blanco) Blume & $\mathrm{N}$ & OWS \\
\hline Dipterocarpaceae & Shorea palosapis (Blanco) Merr. & $\mathrm{N} / \mathrm{E}$ & OWS \\
\hline Dipterocarpaceae & Shorea polysperma (Blanco) Merr. & $\mathrm{N} / \mathrm{E}$ & VU \\
\hline Dipterocarpaceae & Vatica mangachapoi Blanco & $\mathrm{N}$ & VU \\
\hline Ebenaceae & Diospyros blancoi A.DC. & $\mathrm{N}$ & VU \\
\hline Ebenaceae & Diospyros cauliflora Blume & $\mathrm{N}$ & VU \\
\hline Ebenaceae & Diospyros curannii Merr. & $\mathrm{N}$ & OTS \\
\hline Ebenaceae & Diospyros ferrea (Willd.) Bakh. & $\mathrm{N}$ & $\mathrm{CR}$ \\
\hline Ebenaceae & Diospyros pilosanthera Blanco & $\mathrm{N} / \mathrm{E}$ & VU \\
\hline Ebenaceae & Diospyros poncei Merr. & $\mathrm{N} / \mathrm{E}$ & $\mathrm{CR}$ \\
\hline Ebenaceae & Diospyros pyrrhocarpa Miq. & $\mathrm{N} / \mathrm{E}$ & $\mathrm{VU}$ \\
\hline Ebenaceae & Diospyros sp. & $\mathrm{N}$ & OWS \\
\hline Euphorbiaceae & Acalypha indica $\mathrm{L}$. & I & \\
\hline
\end{tabular}


Cont'd Table 4. Taxonomic listing of plants arranged alphabetically by family.

\begin{tabular}{|c|c|c|c|}
\hline Family & Scientific Name & ES & CS \\
\hline Euphorbiaceae & Acalypha sp. & I & \\
\hline Euphorbiaceae & Croton tiglium $\mathrm{L}$. & I & \\
\hline Euphorbiaceae & Endospermum peltatum Merr. & I & \\
\hline Euphorbiaceae & Euphorbia hirta L. & I & \\
\hline Euphorbiaceae & Macaranga bicolor Müll.Arg. & $\mathrm{N} / \mathrm{E}$ & OWS \\
\hline Euphorbiaceae & Macaranga sp. & $\mathrm{N}$ & OWS \\
\hline Euphorbiaceae & Macaranga tanarius (L.) Müll.Arg. & $\mathrm{N}$ & OWS \\
\hline Euphorbiaceae & Manihot esculenta Crantz & I & \\
\hline Fabaceae & Abrus precatorius L. & $\mathrm{N}$ & OWS \\
\hline Fabaceae & Adenanthera intermedia Merr. & $\mathrm{N} / \mathrm{E}$ & OWS \\
\hline Fabaceae & Afzelia rhomboidea (Blanco) S.Vidal & $\mathrm{N}$ & $\mathrm{EN}$ \\
\hline Fabaceae & Albizia acle (Blanco) Merr. & $\mathrm{N}$ & OWS \\
\hline Fabaceae & Albizia falcataria (L.) Fosb. & I & \\
\hline Fabaceae & Bauhinia cumingiana (Benth.) Fern. & $\mathrm{N}$ & OWS \\
\hline Fabaceae & Caesalpinia pulcherrima (L.) Sw. & I & \\
\hline Fabaceae & Calopogonium mucunoides Desv. & I & \\
\hline Fabaceae & Centrosema pubescens auct. non Benth. & I & \\
\hline Fabaceae & Cynometra ramiflora $\mathrm{L}$. & $\mathrm{N}$ & OWS \\
\hline Fabaceae & Cynometra simplicifolia Harms & I & \\
\hline Fabaceae & Derris elliptica (Wall.) Benth. & I & \\
\hline Fabaceae & Desmodium heterocarpon (L.) DC. & I & \\
\hline Fabaceae & Enterolobium cyclocarpum (Jacq.) Griseb. & I & \\
\hline Fabaceae & Erythrina orientalis L. & $\mathrm{N}$ & OWS \\
\hline Fabaceae & Erythrina subumbrans (Hassk.) Merr. & I & \\
\hline Fabaceae & Leucaena leucocephala (Lam.) de Wit & I & \\
\hline Fabaceae & Mimosa pudica L. & I & \\
\hline Fabaceae & Ormosia calavensis Azaola ex Blanco & $\mathrm{N}$ & OWS \\
\hline Fabaceae & Pterocarpus indicus Willd. & $\mathrm{N}$ & VU \\
\hline Fabaceae & Albizia saman (Jacq.) F.Muell & I & \\
\hline Fagaceae & Castanea mollissima Blume & I & \\
\hline Fagaceae & Lithocarpus ovalis (Blanco) Rehder & I & \\
\hline Flagellariaceae & Flagellaria indica $\mathrm{L}$. & I & \\
\hline Gesneriaceae & Epithema sp. & I & \\
\hline Gleicheniaceae & Dicranopteris sp. & $\mathrm{N}$ & OWS \\
\hline Gnetaceae & Gnetum gnemon L. & $\mathrm{N}$ & OWS \\
\hline Hypericaceae & Cratoxylum blancoi Blume & $\mathrm{N} / \mathrm{E}$ & OWS \\
\hline Hypericaceae & Cratoxylon sp. & $\mathrm{N}$ & OWS \\
\hline Hypericaceae & Cratoxylum blancoi Blume & $\mathrm{N}$ & OWS \\
\hline Hypericaceae & Cratoxylum sp. & $\mathrm{N}$ & OWS \\
\hline Lamiaceae & Clerodendrum intermedium Cham. & $\mathrm{N}$ & OWS \\
\hline
\end{tabular}


Cont'd Table 4. Taxonomic listing of plants arranged alphabetically by family.

\begin{tabular}{|c|c|c|c|}
\hline Family & Scientific Name & ES & CS \\
\hline Lamiaceae & Clerodendrum quadriloculare (Blanco) Merr. & $\mathrm{N}$ & VU \\
\hline Lamiaceae & Hyptis sp. & $\mathrm{N}$ & OWS \\
\hline Lamiaceae & Teijsmanniodendron ahernianum (Merr.) Bakh. & $\mathrm{N}$ & OWS \\
\hline Lauraceae & Cinnamomum celebicum Miq. & I & \\
\hline Lauraceae & Cinnamomum mercadoi S.Vidal & $\mathrm{N} / \mathrm{E}$ & OTS \\
\hline Lauraceae & Cinпатотит sp. & $\mathrm{N}$ & OWS \\
\hline Lauraceae & Cinnamomum zeylanicum Blume & $\mathrm{N}$ & OWS \\
\hline Lauraceae & Litsea leytensis Merr. & $\mathrm{N} / \mathrm{E}$ & EN \\
\hline Lauraceae & Litsea sp. & $\mathrm{N}$ & OWS \\
\hline Lauraceae & Neolitsea zeylanica (Nees) Merr. & I & \\
\hline Lauraceae & Persea americana Mill. & I & \\
\hline Lauraceae & Persea philippinensis (Merr.) Elmer & $\mathrm{N} / \mathrm{E}$ & OTS \\
\hline Lygodiaceae & Lygodium circinnatum (Burm.f.) Sw. & I & \\
\hline Lythraceae & Lagerstroemia speciosa (L.) Pers. & $\mathrm{N}$ & \\
\hline Malvaceae & Ceiba pentandra (L.) Gaertn. & I & \\
\hline Malvaceae & Colona serratifolia $\mathrm{Cav}$. & $\mathrm{N}$ & OWs \\
\hline Malvaceae & Diplodiscus paniculatus Turcz. & $\mathrm{N} / \mathrm{E}$ & OWS \\
\hline Malvaceae & Grewia multiflora Juss. & $\mathrm{N}$ & OWS \\
\hline Malvaceae & Grewia sp. & $\mathrm{N}$ & OWS \\
\hline Malvaceae & Microcos sp. & $\mathrm{N}$ & OWS \\
\hline Malvaceae & Microcos stylocarpa (Warb.) Burret & $\mathrm{N}$ & OWS \\
\hline Malvaceae & Pterocymbium tinctorium (Blanco) Merr. & $\mathrm{N}$ & OWS \\
\hline Malvaceae & Pterospermum diversifolium Blume & $\mathrm{N}$ & OWS \\
\hline Malvaceae & Pterospermum niveum S.Vidal & $\mathrm{N}$ & OWS \\
\hline Malvaceae & Pterospermum obliquum Blanco & $\mathrm{N} / \mathrm{E}$ & OWS \\
\hline Malvaceae & Sterculia oblongata R.Br. in Benn. & I & \\
\hline Malvaceae & Sterculia philippinensis Merr. & $\mathrm{N} / \mathrm{E}$ & OWS \\
\hline Malvaceae & Sterculia sp. & $\mathrm{N}$ & OWS \\
\hline Malvaceae & Urena lobata $\mathrm{L}$. & I & \\
\hline Marantaceae & Donax canaeformis (G.Forst.) K.Schum. & I & \\
\hline Marantaceae & Phacelophrynium interruptum Warb. ex K.Schum. & $\mathrm{N}$ & OWS \\
\hline Marattiaceae & Angiopteris evecta Sw. & $\mathrm{N}$ & OWS \\
\hline Marattiaceae & Angiopteris sp. & $\mathrm{I}$ & \\
\hline Marsileaceae & Marsilea minuta $\mathrm{L}$. & $\mathrm{I}$ & \\
\hline Meliaceae & Aglaia edulis (Roxb.) Wall. & $\mathrm{N}$ & OTS \\
\hline Meliaceae & Aglaia pachyphylla Miq. & $\mathrm{N}$ & OWS \\
\hline Meliaceae & Chisocheton pentandrus (Blanco) Merr. & $\mathrm{N}$ & OWS \\
\hline Meliaceae & Dysoxylum arborescens (Blume) Miq. & $\mathrm{N}$ & OWS \\
\hline Meliaceae & Dysoxylum gaudichaudianum (A.Juss.) Miq. & $\mathrm{N}$ & OWS \\
\hline Meliaceae & Lansium domesticum Correa & I & \\
\hline
\end{tabular}


Cont'd Table 4. Taxonomic listing of plants arranged alphabetically by family.

\begin{tabular}{|c|c|c|c|}
\hline Family & Scientific Name & ES & CS \\
\hline Meliaceae & Sandoricum koetjape (Burm.f.) Merr. & I & \\
\hline Meliaceae & Swietenia macrophylla King & I & \\
\hline Meliaceae & Toona calantas Merr. \& Rolfe & $\mathrm{N}$ & VU \\
\hline Menispermaceae & Anamirta cocculus (L.) Wight \& Arn. & $\mathrm{N}$ & OWS \\
\hline Moraceae & Artocarpus odoratissimus Blanco & $\mathrm{N}$ & OWS \\
\hline Moraceae & Artocarpus altilis (Park.) Fosb. & $\mathrm{N}$ & OWS \\
\hline Moraceae & Artocarpus blancoi (Elmer) Merr. & $\mathrm{N} / \mathrm{E}$ & OWS \\
\hline Moraceae & Artocarpus heterophyllus Lam. & I & \\
\hline Moraceae & Artocarpus nitidus (Merr.) F.M. Jarrett & $\mathrm{N}$ & OWS \\
\hline Moraceae & Ficus ampelas Burm.f. & $\mathrm{N}$ & OWS \\
\hline Moraceae & Ficus balete Merr. & $\mathrm{N} / \mathrm{E}$ & OWS \\
\hline Moraceae & Ficus fistulosa Reinw. ex Blume & $\mathrm{N}$ & OWS \\
\hline Moraceae & Ficus nota (Blanco) Merr. & $\mathrm{N}$ & OWS \\
\hline Moraceae & Ficus pseudopalma Blanco & $\mathrm{N} / \mathrm{E}$ & OWS \\
\hline Moraceae & Ficus septica Burm.f. & $\mathrm{N}$ & OWS \\
\hline Moraceae & Ficus sp. & $\mathrm{N}$ & OWS \\
\hline Moraceae & Ficus sp. & $\mathrm{N}$ & OWS \\
\hline Moraceae & Ficus variegata Blume & $\mathrm{N}$ & OWS \\
\hline Moraceae & Parartocarpus sp. & $\mathrm{N}$ & OWS \\
\hline Muntingiaceae & Muntingia calabura L. & I & \\
\hline Musaceae & Musa $x$ sapientum $\mathrm{L}$. & I & \\
\hline Musaceae & Musa sapientum L. var. cinerea (Blanco) Teodoro & I & \\
\hline Musaceae & Musa sp. & I & \\
\hline Musaceae & Musa sp. & I & \\
\hline Myristicaceae & Knema glomerata (Blanco) Merr. & $\mathrm{N} / \mathrm{E}$ & OWS \\
\hline Myristicaceae & Myristica elliptica Wall. ex Hook.f. & $\mathrm{N}$ & OWS \\
\hline Myristicaceae & Myristica philippensis Lam. & $\mathrm{N} / \mathrm{E}$ & OTS \\
\hline Myrsinaceae & Ardisia sp. & I & \\
\hline Myrtaceae & Eugenia uniflora L. & $\mathrm{N}$ & OWS \\
\hline Myrtaceae & Psidium guajava $\mathrm{L}$. & I & \\
\hline Myrtaceae & Syzygium crassipes (C.B.Rob.) Merr. & $\mathrm{N} / \mathrm{E}$ & OWS \\
\hline Myrtaceae & Syzygium longiflorum C.Presl & $\mathrm{N}$ & OWS \\
\hline Myrtaceae & Syzygium nitidum Benth. & $\mathrm{N}$ & VU \\
\hline Myrtaceae & Syzygium polycephaloides (C.B.Rob.) Merr. & $\mathrm{N}$ & OWS \\
\hline Myrtaceae & Syzygium sp. & $\mathrm{N}$ & OWS \\
\hline Myrtaceae & Syzygium sp. & I & \\
\hline Myrtaceae & Tristanopsis decorticata (Merr.) PeterG.Wilson \& J.T.Waterh. & $\mathrm{N} / \mathrm{E}$ & VU \\
\hline Nephrolepidaceae & Nephrolepis exaltata W.H. Wagner & I & \\
\hline Nephrolepidaceae & Nephrolepis sp. & I & \\
\hline Nyctaginaceae & Pisonia umbellifera (J.R.Forst. \& G.Forst.) Seem. & $\mathrm{N}$ & OWS \\
\hline
\end{tabular}


Cont'd Table 4. Taxonomic listing of plants arranged alphabetically by family.

\begin{tabular}{|c|c|c|c|}
\hline Family & Scientific Name & ES & CS \\
\hline Olacaceae & Strombosia philippinensis (Baill.) Rolfe & $\mathrm{N} / \mathrm{E}$ & OWS \\
\hline Oleaceae & Jasminum sambac (L.) Aiton & $\mathrm{N}$ & OWS \\
\hline Oleaceae & Linociera ramiflora (Roxb.) Wall. & I & \\
\hline Onagraceae & Ludwigia sp. & I & \\
\hline Pandanaceae & Pandanus luzonensis Merr. & $\mathrm{N} / \mathrm{E}$ & OWS \\
\hline Passifloraceae & Passiflora foetida $\mathrm{L}$. & I & \\
\hline Phyllanthaceae & Antidesma sp. & $\mathrm{N}$ & OWS \\
\hline Phyllanthaceae & Breynia cernua (Poir.) Müll.Arg. & $\mathrm{N}$ & OWS \\
\hline Phyllanthaceae & Glochidion philippicum (Cav.) C.B.Rob. & $\mathrm{N}$ & OWS \\
\hline Phyllanthaceae & Glochidion sp. & $\mathrm{N}$ & OWS \\
\hline Phyllanthaceae & Phyllanthus buxifolius (Blume) Müll.Arg. & $\mathrm{N}$ & OWS \\
\hline Phyllanthaceae & Phyllanthus niruri auct. non $\mathrm{L}$. & I & \\
\hline Phyllanthaceae & Phyllanthus sp. & $\mathrm{N}$ & OWS \\
\hline Piperaceae & Peperomia microphylla Dahlst. & I & \\
\hline Piperaceae & Peperomia pellucida (L.) Kunth & I & \\
\hline Piperaceae & Piper betle L. & $\mathrm{N}$ & OWS \\
\hline Poaceae & Axonopus compressus (Sw.) P.Beauv. & $\mathrm{N}$ & OWS \\
\hline Poaceae & Bambusa multiplex (Lour.) Raeusch. & I & \\
\hline Poaceae & Chrysopogon aciculatus (Retz.) Trin. & I & \\
\hline Poaceae & Coix lacryma-jobi $\mathrm{L}$. & I & \\
\hline Poaceae & Dinochloa scandens (Blume ex Nees) Kuntze & $\mathrm{N}$ & OWS \\
\hline Poaceae & Eleusine indica (L.) Gaertn. & I & \\
\hline Poaceae & Imperata cylindrica (L.) P.Beauv. & $\mathrm{N}$ & OWS \\
\hline Poaceae & Panicum maximum Jacq. & I & \\
\hline Poaceae & Panicum sp. & I & \\
\hline Poaceae & Paspalum conjugatum P.J.Bergius & I & \\
\hline Poaceae & Paspalum distichum auct. non $\mathrm{L}$. & I & \\
\hline Poaceae & Saccharum spontaneum $\mathrm{L}$. & I & \\
\hline Podocarpaceae & Podocarpus polystachyus R.Br. ex Endl. & $\mathrm{I}$ & \\
\hline Polygonaceae & Triplaris cumingiana Fisch. \& C.A.Mey. ex C.A.Mey. & $\mathrm{I}$ & \\
\hline Pteridaceae & Adiantum pedatum $\mathrm{L}$. & $\mathrm{N}$ & OWS \\
\hline Pteridaceae & Adiantum sp. & I & \\
\hline Pteridaceae & Pteris sp. & I & \\
\hline Putranjivaceae & Drypetes longifolia (Blume) Pax \& Hoffm. & $\mathrm{N}$ & OWS \\
\hline Rosaceae & Prunus grisea (Blume) Kalkm. & $\mathrm{N}$ & OWS \\
\hline Rubiaceae & Antherostele sp. & $\mathrm{N}$ & OWS \\
\hline Rubiaceae & Canthium horridum Blume & I & \\
\hline Rubiaceae & Coffea robusta L.Linden & I & \\
\hline Rubiaceae & Coffea canephora Pierre ex A.Froehner & I & \\
\hline Rubiaceae & Nauclea orientalis (L.) L. & $\mathrm{N}$ & OWS \\
\hline
\end{tabular}


Cont'd Table 4. Taxonomic listing of plants arranged alphabetically by family.

\begin{tabular}{|c|c|c|c|}
\hline Family & Scientific Name & ES & CS \\
\hline Rubiaceae & Nauclea sp. & $\mathrm{N}$ & OWS \\
\hline Rubiaceae & Neonauclea calycina (Bartl. ex DC.) Merr. & $\mathrm{N}$ & OWS \\
\hline Rubiaceae & Psychotria elliptifolia Elmer & $\mathrm{N} / \mathrm{E}$ & OWS \\
\hline Rubiaceae & Psychotria manillensis Bartl. ex DC. & $\mathrm{N} / \mathrm{E}$ & OWS \\
\hline Rubiaceae & Psychotria membranifolia Merr. & $\mathrm{N}$ & OWS \\
\hline Rubiaceae & Psychotria microphylla Elmer & $\mathrm{N} / \mathrm{E}$ & OWS \\
\hline Rubiaceae & Psychotria ovalis Elmer & $\mathrm{N} / \mathrm{E}$ & OWS \\
\hline Rubiaceae & Psychotria pauciflora Bartl. ex DC. & $\mathrm{N} / \mathrm{E}$ & OWS \\
\hline Rubiaceae & Psychotria rubiginosa Elmer & $\mathrm{N} / \mathrm{E}$ & OWS \\
\hline Rubiaceae & Psychotria sp. & $\mathrm{N}$ & OWS \\
\hline Rutaceae & Citrus grandis Osbeck & I & \\
\hline Rutaceae & Citrus reticulata Blanco & I & \\
\hline Rutaceae & Citrus sp. & I & \\
\hline Rutaceae & Lunasia amara Blanco & I & \\
\hline Rutaceae & Zanthoxylum limonella (Dennst.) Alston & I & \\
\hline Salicaceae & Homalium bracteatum Benth. & $\mathrm{N} / \mathrm{E}$ & OWS \\
\hline Sapindaceae & Dimocarpus longan Lour. & I & \\
\hline Sapindaceae & Ganophyllum falcatum Blume & $\mathrm{N}$ & OWS \\
\hline Sapindaceae & Guioa discolor Radlk. & $\mathrm{N} / \mathrm{E}$ & VU \\
\hline Sapindaceae & Guioa koelreuteria (Blanco) Merr. & $\mathrm{N}$ & OWS \\
\hline Sapindaceae & Litchi chinensis Sonn. spp. philippinensis (Radlk.) Leenh. & $\mathrm{N} / \mathrm{E}$ & VU \\
\hline Sapindaceae & Nephelium lappaceum L. & $\mathrm{N}$ & VU \\
\hline Sapindaceae & Nephelium ramboutan-ake (Labill.) Leenh. & $\mathrm{N}$ & OWS \\
\hline Sapotaceae & Ganua obovatifolia (Merr.) Assem & $\mathrm{N}$ & OWS \\
\hline Sapotaceae & Madhuca obovatifolia (Merr.) Merr. & $\mathrm{N} / \mathrm{E}$ & EN \\
\hline Sapotaceae & Mimusops elengi L. & $\mathrm{N}$ & OWS \\
\hline Sapotaceae & Palaquium barnesii auct. non Merr. & $\mathrm{N} / \mathrm{E}$ & OWS \\
\hline Sapotaceae & Palaquium formosanum Hayata & I & \\
\hline Sapotaceae & Palaquium lanceolatum Blanco & $\mathrm{N} / \mathrm{E}$ & OWS \\
\hline Sapotaceae & Palaquium philippinense H.J.Lam & $\mathrm{N} / \mathrm{E}$ & VU \\
\hline Sapotaceae & Planchonella villamilii (Merr.) Swenson & $\mathrm{N} / \mathrm{E}$ & VU \\
\hline Sapotaceae & Pouteria macrantha (Merr.) Baehni & $\mathrm{N}$ & OWS \\
\hline Selaginellaceae & Selaginella cumingiana Spring & $\mathrm{N}$ & OWS \\
\hline Selaginellaceae & Selaginella cupressina (Willd.) Spring & $\mathrm{N}$ & OWS \\
\hline Solanaceae & Capsicum frutescens $\mathrm{L}$. & I & \\
\hline Solanaceae & Solanum biflorum Lour. & I & \\
\hline Solanaceae & Solanum cumingii Dunal in DC. & $\mathrm{N}$ & OWS \\
\hline Stemonuraceae & Gomphandra cumingiana (Miers) Fern. & $\mathrm{N}$ & OWS \\
\hline Tetramelaceae & Octomeles sumatrana Miq. & $\mathrm{N}$ & OWS \\
\hline Urticaceae & Dendrocnide meyeniana (Walp.) Chew & $\mathrm{N}$ & OWS \\
\hline
\end{tabular}


Cont'd Table 4. Taxonomic listing of plants arranged alphabetically by family.

\begin{tabular}{|l|l|l|l|}
\hline \multicolumn{1}{|c|}{ Family } & \multicolumn{1}{c|}{ Scientific Name } & \multicolumn{1}{c|}{ ES } & \multicolumn{1}{c|}{ CS } \\
\hline Urticaceae & Elatostema elmeri Merr. & N/E & OWS \\
\hline Urticaceae & Pipturus arborescens (Link) C.B.Rob. & I & \\
\hline Verbenaceae & Lantana camara L. & I & \\
\hline Verbenaceae & Stachytarpheta jamaicensis (L.) Vahl & I & \\
\hline Vitaceae & Leea aculeata Blume ex Sprengel & N & OWS \\
\hline Vitaceae & Leea sp. & N & OWS \\
\hline Zingiberaceae & Alpinia foxworthyi Ridl. & N/E & VU \\
\hline Zingiberaceae & Alpinia haenkei C.Presl & N & OWS \\
\hline Zingiberaceae & Alpinia pubiflora (Benth.) K.Schum. & N & OWS \\
\hline Zingiberaceae & Alpinia zerumbet (Pers.) B.L.Burtt \& R.M.Sm. & I & \\
\hline
\end{tabular}

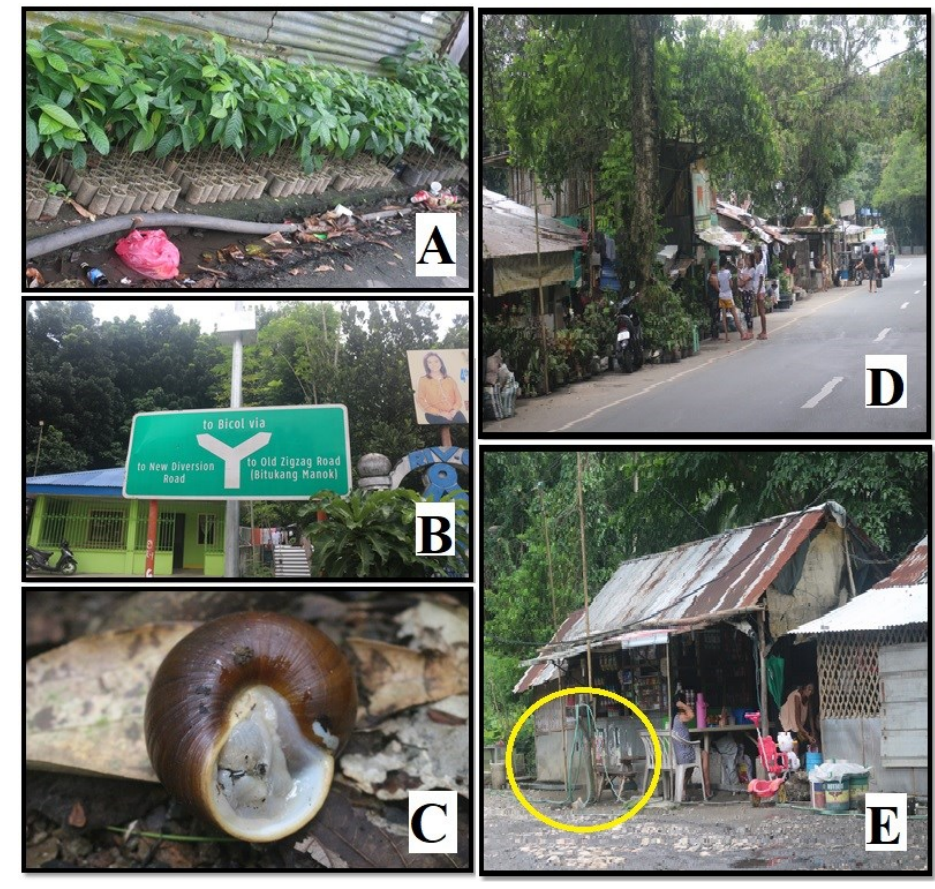

Figure 5. Threats encountered at QPL while conducting the study. A. Mahogany saplings; B. Main roads going to Bicol region; C. Gathering of "bayuko"; D. Rural residentials inside the QPL; E. Carwashing business inside the QPL.

Ageratum conyzoides L., Calopogonium mucunoides Desv., Chromolaena odorata L., Lantana camara L., Leucaena leucocephala (Lam.) de Wit, Melothria pendula L., Mikania cordata (Burm.f.) B.L. Rob., Mimosa pudica L., Stachytarpheta jamaicensis (L.) Vahl., and Triplaris cumingiana Fisch. \& Mey. (Paclibar \& Tadiosa, 2019).
All observed threats were not imminently bad because efforts of the LGU and the protected area superintendent (PASu) are in place in mitigating such problems through several programs and projects which promote sustainability and conservation efforts. Notwithstanding, encroachment can be considered most serious because human activities are directly involved in all of the disturbances seen in the area especially in the collection and extraction of natural resources as well as the cleanliness.

\section{Recommendations for $Q P L$}

Since the threats are mostly from anthropogenic activities and invasive alien species, it is highly recommended that protection and awareness campaigns should be done. Protection can be achieved through surveillance, patrolling, and close monitoring of the areas especially in the lowland evergreen rainforest and karst forest. For the secondary forests, rehabilitation should be prioritized to avoid forest simplification and to prevent the non-native species from outcompeting the native plants. In line with this, joint efforts coming from the LGUs, PAMB and stakeholders for awareness campaign are a must to educate the residents staying adjacent to QPL.

\section{Conclusion and Recommendations}

QPL has a wide array of plant species. It consists of 328 plant species belonging to 84 families and 208 genera. Among the 172 tree species identified, Parashorea malaanonan is deemed to be the most important in lowland evergreen rainforest and in mixed or emerging lowland evergreen rainforest; Diospyros pyrrhocarpa in the karst forest; Leucaena 
leucocephala in the secondary forest; and Cocos nucifera in the agroforest. Of the different vegetation types, Macaranga tanarius is one of the most important species except in the karst forest which also suggests disturbance to the area. There are 65 endemic out of 213 native plants implying that endemicity is quite low $(19.82 \%)$. Out of 45 threatened species recorded, 25 are endemic. Threats encountered include illegal collection of natural resources, encroachment, cleanliness, and presence of invasive alien species, despite the efforts of the LGU and the PASu in the mitigation of such problems through several programs and projects which promote sustainability and conservation.

\section{Acknowledgement}

The authors would like to express their gratitude to the following people, institutions, and agencies who helped complete the study successfully. The deepest gratitude to the following: Lyceum of the Philippines University (LPU) for the support; Department of Environment and Natural Resources-Protected Area Management Board (DENR-PAMB) for the approval to conduct the study and National Mapping and Resource Information Authority (NAMRIA) for providing the map of QPL.

\section{Literature Cited}

Amoroso, V.B., S.H. Laraga \& B.V. Calzada, 2011. Diversity and assessment of plants in Mt. Kitanglad Range Natural Park, Bukidnon, Southern Philippines. Gardens' Bulletin Singapore, 63: 219-236.

Arsenio, J.J., M.P. Medecilo, E.T. Mercado, E.T. Salibay \& F.A.H. Valera, 2011. The vegetation of Mt. Maculot, Cuenca, Batangas, Philippines. International Journal of Environmental Science and Development, 2:274-278.

Borja, V.G.L., D.B. Magcale-Macandog, I.A.F. Lambio, R. Brandl, S. Hotes, J. Settele \& M. Wiemers, 2015.Spatial patterns and plant species associations of coffee (Coffea spp.) along the eastern slopes of Mount Makiling Forest Reserve, Luzon, Philippines. CiteSeerx The Pennsyvania University, 1-10.

Brower, J.E. \& J.H. Zar. 1977. Field and laboratory methods of general ecology. Wm. C. Brown Company Publishers, Dubuque, Iowa. 194p.

Brown, R., C.D. Siler, C.H. Oliveros, J.A. Esselstyn, A.C. Diesmos, P.A. Hosner, C.W. Linkem, A.J. Barley, J.R. Oaks, M.B. Sanguila, L.J. Welton, D.C. Blackburn, R.G. Moyle, A.T. Peterson \& A.C. Alcala, 2013. Evolutionary diversification of vertebrates in the Philippines. Annual Review of Ecology, Evolution, and Systematics, 44: 411-435. Camargo, J.A., 1995. On measuring species evenness and other associated parameters of community structure. Oikos, 74: 538-542.

Cardenas, L.B., M.A.O. Cajano, B.F. Hernaez, \& N.O. Aguilar, 2001. Some Flowering Plants on the Southern Slope of Mount Isarog, Camarines Sur, Philippines. University of the Philippines at Los Baños, Laguna, Philippines.

Causaren, R.M., R.D. Lagat, \& E.M.G. Agoo, 2017. Tree species diversity of the remaining forest fragments in Cavite, Luzon Island, Philippines. Philippine Journal of Systematic Biology, 11: 56-73.

Center for Agriculture and Bioscience International (CABI). 2020. Macaranga tanarius (parasol leaf tree). https:// www.cabi.org/isc/datasheet/32763\#tosummaryOfInvasiveness

Climate-Data.org, 2019. Atimonan climate. https://en.climatedata.org/asia/philippines/quezon/atimonan-20171/

Dagamac, N.H.A., M.A.D. Rea-Maminta, \& T.E.E. Dela Cruz, 2014. Plasmodial slime molds of a tropical karst forest, Quezon National Park, the Philippines. Pacific Science, 69: 1-22.

De Guzman, E.D., R.M. Umali, \& E.D. Sotalbo, 1986. Guide to Philippine flora and fauna (Dipterocarps and NonDipterocarps). Natural Resources Management Center and the University of the Philippines. Vol. III. JMC Press Inc., Quezon City.

Department of Environment and Natural ResourcesBiodiversity Management Bureau (DENR-BMB), 2014. The fifth national report to the convention on biological diversity. Diliman, Quezon City: Department of Environment and Natural Resources.

Department of Environment and Natural Resources (DENR) Administrative Order No. 2017-11. Updated national list of threatened Philippine plants and their categories. Diliman, Quezon City: Department of Environment and Natural Resources.

Department of Environment and Natural Resources Region IV-A CALABARZON, 2013. Quezon protected landscape. http://portal.calabarzon.denr.gov.ph/ecotourism/ Protected_Quezon.html

Drearly, F.Q., Banin, L.F. \& P. Saner. 2016. The ecology of the Asian dipterocarps. Plant Ecology and Diversity, 9:5 $-6,429-436$.

Fernando, E.S., L.L. Co, D.A. Lagunzad, W.SM. Gruezo, J.F. Barcelona, D.A. Madulid, A.B. Lapis, G.I. Texon, A.C. Manila \& P.M. Zamora, 2008. Threatened plants of the Philippines: a preliminary assessment. Asia Life Sciences, The Asian International Journal of Life Sciences, Supplement 3.

Ferreras, U.F, R.A. Achacoso, A.T. Arbias, A.M. Navarro, 
V.C. Peralejo, \& L.G. Soriano, 2014. A Pictorial Guide to the Native Plants of Mt. Tapulao. Philippine Native Plants Conservation Society of the Philippines, Inc., Diliman, Quezon City.

Keong, C.Y., 2015. Sustainable resource management and ecological conservation of megabiodiversity: The Southeast Asian big-3 reality. International Journal of Environmental Science and Development, 6: 876-882.

Lembrechts, J.J., J.M. Alexander, L.A. Cavieres, S. Haider, J. Lenoir, C. Kueffer, K. McDougall, B.J. Naylor, M.A. Nunez, A. Pauchard, L.J. Rew, I. Nijs \& A. Milbau, 2016. Mountain roads shift native and non-native plant species' ranges. Wiley Online Library Ecography, 40: 353-364.

Madulid, D.A., 2000. Philippine Plants: Endangered Plants. Island Publishing House, Inc.

Magurran, A.E., 1998. Ecological Diversity and Its Measurement. Princeton University Press, Princeton, New Jersey.

Medecilo, M.M.P. \& M.P. Lagat, 2017. Floristic composition of the remaining forests in upland Cavite, Luzon Island, Philippines. Philippine Journal of Systematic Biology, 11: 74 $-94$.

Mittermeier, R.A., N. Myers, P.R. Gil, \& C.G. Mittermeier, 1999. Hotspots: Earth's Biologically Richest and Most Endangered Terrestrial Ecoregions. Cemex, Conservation International, and Agrupacion Sierra Madre, Monterey, Mexico.

Nijs I., M. Verlinden, P. Meerts, N. Dassonville, S. Domken, L. Triest \& G. Mahy, 2012. Biodiversity impacts of highly invasive plants: mechanisms, enhancing factors and risk assessment. Science for a Sustainable Development (SSD). Belgian Science Policy, Avenue Louise 231, Brussels, Belgium.

Pacific Consultants International (PCI), 2006. Flora survey and biodiversity assessment for core zoning Municipality of Busuanga. Palawan Council for Sustainable Development.

Paclibar, G.C.B. \& E.R. Tadiosa, 2019. Ecological niche modelling of invasive alien plant species in a protected landscape. Global Journal of Environmental Science and Management, 5: 371-382.

Pahlevani, A.H. \& H. Akhani. 2011. Seed morphology of Iranian annual species of Euphorbia (Euphorbiaceae). Botanical Journal of the Linnaean Society, 167: 212-234.

Pelser, P.B., J.F. Barcelona \& D.L. Nickrent. (eds.), 2011 onwards. Co's Digital Flora of the Philippines. www.philippineplants.org

Persoon, G.A.\& M. Van Weerd, 2006. Biodiversity and natural resource management in insular Southeast Asia. Islands Studies Journal, 1: 81-108.

Petraitis, P.S., R.E. Latham, \& R.A. Niesenbaum, 1989. The maintenance of species diversity by disturbance. The Quarterly Review of Biology, 64(4): 393-418.

Philippine Tropical Forest Conservation Foundation (PTFCF), 2015. Status of Philippine Forests. Philippine Tropical Forest Conservation Foundation, Inc., pp. 11.

Pielou, E. 1966. The measurement of diversity in different types of biological collections. Journal of Theoretical Biology, 13: 131-144.

Polinar, A.N. \& U. Muuss. 2010. Tree species diversity in secondary forest of Mount Pangasugan, Baybay City, Philippines. Journal of Nature Studies, 9(1): 105-111.

Replan, E.L. \& A.B.B. Malaki, 2017. Floral diversity and habitat assessment of Cabantug forest, Argao, Central Visayas, Cebu, Philippines. International Journal of Scientific \& Engineering Research, 8: 775-710.

Rojo, J.P., 1997. Botanical Identification Handbook on Philippine Dipterocarps. Forest Products Research and Development Institute, Department of Science and Technology, College, Laguna.

Rojo, J.P., 1999. Lexicon of Philippine Trees. Forest Products Research and Development InstituteDepartment of Science and Technology. College, Laguna.

Rojo, J.P., 2000. Species diversity and conservation status of Philippine dipterocarps. Forest Products Research and Development Institute, Los Banos.

Rojo, J.P., \& E.G. Aragones, 1998. Field Guide to the Identification of Important Lesser-Used Species of Philippine Timbers. International Tropical Timber Organization and Forest Products Research and Development Institute, College, Laguna.

Sajise, P. \& V. Cuevas, 1995. Manual on vegetational analysis for grassland and forest ecosystem. Philippine Council for Agriculture, Forestry and Natural Resources Research and Development, Department of Science and Technology.

Shaheen, H., S.M. Khan, D.M. Harper, Z. Ullah, \& R.A. Qureshi, 2011. Species diversity, community structure, and distribution patterns in Western Himalayan alpine pastures of Kashmir, Pakistan. Mountain Research and Development, 31(2): 153-159.

Smith. R.L. \& T.M. Smith, 2004. Elements of Ecology. $5^{\text {th }}$ Ed. Pearson Education South Asia Pte. Ltd.

Spear, D., L.C. Foxcroft, H. Bezuidenhout \& M.A. McGeoch, 2013. Human population density explains alien species richness in protected areas. Biological Conservation, 159: 137-147.

Tadiosa, E.R., J.M. Santos, M.A. Cudiamat, M.A. Cruzate, E.J.M. Arma, D.C.G. Hilapo \& H.H. Biscocho, 2016. 
Analysis of forest and grassland vegetation at southwestern side of Quezon Protected Landscape, Southern Luzon, Philippines. International Association of Multidisciplinary Research, 19: 53-59.

Von Rintelen K., E. Arida \& C. Hauser, 2017. A review of biodiversity-related issues and challenges in megadiverse Indonesia and other Southeast Asian countries. Research Ideas and Outcomes, 3: 1-16.

Witt, A., 2017. Guide to the Naturalized and Invasive Plants of Southeast Asia. CAB International, Wallingford, UK. 